\title{
Poetry in School - the Old Issues and New Challenges
}

\section{Vlasta Řeřichová, Jaroslav Vala, Jana Sladová}

\begin{abstract}
The study presents the progress and partial results of the longitudinal research phase of a project in which eight experimental classes participating in the teaching of poetry based on experiential learning and creativity of pupils were observed. The focus is on the results of the selected class of pupils at a primary school in the age group of 12-13 years, particularly $18 \mathrm{girls}$ and 13 boys. Some of the methods used in the work with poetic texts were introduced focusing primarily on poetry perception by teachers and pupils. The results show that the experimental teaching activity appears to be particularly beneficial for the pupils with worse study results who had not initially had a positive relationship to poetry.
\end{abstract}

Key words: reception of poetry, pubescent readers, literary education, experiment

\section{Introduction}

The contemporary modern pedagogy - unlike the normative pedagogy the insights of which had prevailed in the educational process for more than two centuries developing a theoretical system tied primarily to the concepts of education and training - conceives the process of education in a broader context. It includes the whole complex of educational phenomena as well as processes operating outside the school environment. The educational process in our research emphasizes the work with poetic texts and 
highlights their specificities. These texts can serve teachers as an educational resource to achieve defined educational objectives, but also as a behaviour development tool using the educational model of indirect teaching activities which through experience in a particular teaching situation shapes not only the cognitive, but also the emotional aspect of personality (Pelikán, 2009). For this indirect effect the emotions of pupils is particularly significant as well as the process of creating their own personal experiences.

This study presents the progress and partial results of the longitudinal research phase of pubescent poetry readers in eight experimental classes where teaching of poetry was based on experiential learning and creativity of pupils (Vala, 2013). The focus was on the results of the pupils from selected classes of primary schools in the age group of 12-13 years, particularly 18 girls and 13 boys. Some of the methods were introduced with the focus mainly on the perception of the process by teachers and pupils. The control class consisted of 12 girls and 9 boys.

\section{Theoretical basis}

The theoretical basis of the research is the theory of didactic content knowledge proposed by Shulman (1987) as one of the fundamental knowledge bases of teachers. It indicates a specific combination of several components that teachers use to shape their subjective knowledge into a form suitable for teaching. The key role that is of interest to researchers is attributed to transformation processes through which teachers' content knowledge changes into the content knowledge suitable for teaching, i. e. the didactic content knowledge. In teachers' education, the emphasis must be on what subject matter is selected to teach and why a specific curriculum is taught in this one particular way.

As indicated by Janík, Lokajíčková and Janko (2012), the quality of teaching cannot be described simply by listing its characteristics, i.e. that teaching should be clear, structured, activating, etc. It is necessary to specify what the listed adjectives refer to.

As one of the main components of the quality teaching the authors reported learning tasks involving the activation of cognitive function. The general concept of learning tasks calls for active pupil learning activities; based on the subject they move towards the goal of learning; they establish an educational situation determining its form, organization and process (Slavík, Dytrtová, Fulková, 2010). Without learning tasks teaching would lose its own content. In literary education the role of learning tasks is played predominantly by literary texts.

Working with poetic texts in school and seeking ways to make poetry accessible for adolescent readers has been a long-standing and always relevant issue of literary education in schools. According to Vala (2011), poetry in the contemporary school has a difficult position being perceived as incomprehensible by pupils and removed from their life experience, and - as a result of today's pragmatic view focusing on applicability 
of acquired knowledge and skills - considered unnecessary. A lack of pupils' interest in poetry demonstrated by our own and foreign research (Wiseman, 2011; Hanratty, 2012), or even dislike of it are often exacerbated by stereotypical approaches of teachers who prefer a pre-determined and unequivocal answers not allowing the poem to become a living component of didactic communication. A separate issue is the relationship some teachers have with poetry which is influenced, among other things, by their own uncertainty and fear about potential issues associated with interpretation ambiguity of poetic texts (Ofsted, 2007; Vala, 2012; Lambirth et al., 2012). Another factor affecting the work with poetry in schools is a frequent reluctance of pubescents to communicate their feelings concerning poetic text resulting from the fear that their opinion will differ from the opinion of their classmates (Homolová, 2008). Gejgušová (2009) also points out that in the present tough and merciless environment printed text competes with video and audio communication with reading often losing in the conflict.

In the context of the outcomes formulated by the Framework Educational Programme for Basic Education and the framework educational programs for secondary schools these facts became the basis of the project GA CR P407/11/0594 Analysis of Readers' Reception of Poetic Texts in Adolescent Readers. The pupils' (ages 12-19) perception of poetry was investigated as well as the possibilities of influencing the relationship by teaching methods. The implemented longitudinal intervention study allows us to predict the effects of a specific way of presenting the curriculum, it connects the pupils' world with the subject and shows ways of a sensitive guidance of the reflections and discussions related to learning tasks (in this case to poems). This fulfils one of the requirements for a development of the knowledge base of teachers based on didactic content knowledge, especially on the ability to transform the subject knowledge into a form acceptable to pupils.

The teachers involved in the longitudinal project had received twenty ideas for their lessons to choose from (and possibly modify to suit their needs) to try out in their classes. In addition to these subjects they were given five activities described in a detail that were supposed to be implemented (some repeatedly) before the end of 2011 in every experimental class:

- What is a poem - a research in the experimental classes according to specified criteria We strive to make pupils think about the essence of poetry; about their own internal definition which they can check when assessing 14 different texts.

- Filling the missing words (or verses) into poetic texts

This activity is understood as a preparation for writing one's own poetry. Pupils' work is compared with the original, semantic shifts are observed and pupils' reflections recorded.

- Coming repeatedly back to a more challenging text

Select a motivating, provocative, mysterious poetic text without the author and title with pupils recording their reading responses under different circumstances: 

a) immediately after reading the text;
b) after discussing the text with classmates (without comments offered by teach- ers);
c) after obtaining information about the author, time and circumstances of writing of the poem.

- $\quad$ Converting the poem into prose and back

The role of pupils is to realize, through the comparison of different forms of formal poetry, the basic attributes of poetry.

- $\quad$ Poetry writing

Pupils should be guaranteed anonymity, later they can declare themselves as authors of their work. The involvement of the entire class in the evaluation of the texts proves beneficial. The diaries provide their reflection of the activity. Pupils write down their impressions after the task and again after the evaluation of results.

\section{Research Methodology}

Due to the given topic a mixed design research was utilized. The quantitative part was based on the results of the survey mapping the shift in the pupils' perception of poetry, methods of teaching and reflections of their teachers. In the experimental class the work on the project was launched (pre-tested) and finalized (post-tested) by a questionnaire in which the respondents recorded on a five point scale their agreement or disagreement with a series of statements related to poetry and the methods of teaching, not only in terms of reading preferences or reception of poetic text, but also from the perspective of literary communication. The questionnaire therefore investigated the pupils' preconcepts in relation to poetry and its teaching and showed which pupils' attitudes are easier to influence by appropriate teaching. The same questionnaire was completed by the pupils in the control class where standard instruction was implemented.

Similarly to the research conducted by Wiseman (2011), the qualitative line of our research focused on the analysis of the pupils' own work and personal diaries each pupil was keeping during the implementation of the research. The diaries summarized an overview of the tasks, applied teaching methods and forms of schoolwork, but they registered authentic material consisting of observations, impressions, and structures of thought and creative achievements of the monitored pupils as well. A part of the qualitative research line was in the form of interviews with teachers and their written reflection of the implemented teaching.

The longitudinal research started in March 2011, initially in eight classrooms (both at primary and secondary level). They served as experimental classes, i. e. in these classes the literary education was taught according to our plan focusing in detail on the work 
with poetic texts. Concurrently, there was the standard instruction implemented in control classes where teachers continued to teach in their standard way. However, during the implementation of the experimental teaching process cooperation with three of the schools had been terminated due to changes of personnel or inability of the teachers to implement experimental teaching and incorporate its elements into their standard teaching process. The research had lasted 16 months and was completed in June 2012.

\section{Process and results of the qualitative line of the research in the experimental class (ages 12-13)}

In this section selected teaching activities are described as well as their adoption by the pupils and their teacher, and their diaries and creative achievements are analysed. Special attention is given to those pupils whose positive or negative changes in relation to poetry and its teaching have been significant.

\subsection{Internal definition of poetry}

During the initial activity of the experimental class the pupils assessed 14 short texts (including a nursery rhyme, rhyming shopping list, a poem converted into prose etc.) with the aim of establishing their view of a poetic text. The intention was to make them think about the essence of poetry and enable them to develop their own internal definition of poetry which they should later try to explain, as a sort of game, to an alien who had never read any poem. The task had presented the pupils with some difficulties, they suggested rhyme, similarly to foreign pupils in a similar research (Certo et al., 2010), as the primary significant feature of poetry. In several cases they mentioned a verse or verses arranged in stanzas and occasionally rhythm. Very few of them related poems to emotional experience (it must be pleasant, should be funny, moving), in their terms, however, the term pleasant often coincided with the concept of rhymes. Only exceptionally the children acknowledged other aspects of the poem than the feelings poetic texts inspire in recipients, admitting that a poem can have a deeper meaning. They were, however, able to express this dimension of poetry in very simple terms and inaccurately (a poem text is a rhyming text, expressing feelings; it is something that rhymes and moves us). 


\subsection{Filling in missing words in poems}

The further activities of the pupils included filling in missing words in the poems by V. Holan The Last Leaf, M. Černík's Each bird has its own song and M. Jirous's The little clouds asked the heaven. The most difficult part for the pupils was filling in the gaps in the poem by V. Holan. The poem, with its title and the name of the author deleted, was adjusted so that the pupils could, while preserving the overall atmosphere of the text, use their imagination and creativity as much as possible. The underlined words were omitted in the text.

\section{Vladimír Holan - The Last Leaf}

The last leaf trembles on the plane-tree

For it knows well that without shaking there is no firmness.

I tremble, God, because I feel

I shall soon die and should be firm.

From every tree falls the last leaf

For it is not without faith in the earth.

From every man falls the last pretence

For the mortuary slab is utterly simple.

The leaf has no need to ask you, God, for anything -

You made it grow and it has not spoilt Your hand.

But I...

This task was difficult for pupils, however their comments in the reading diaries suggested that the work was interesting and significantly motivating: I really liked this task, l enjoyed it a lot because we had a good laugh, when we were inventing funny words that would have fitted but were not making much sense. Super. If we write this ever again, my head will burst, but otherwise it was good. It was quite funny and interesting trying something new.

A deeper insight into the way of solving the task is offered by a more detailed characteristics of the children (and an analysis of their work and reflections), based on the entry questionnaire they seemed to be non-readers with a significantly negative relationship to poetry, but the exit questionnaire had shown a significant positive change in their attitude to poetry. Further characteristics of the pupils were provided by their teacher:

- Jakub D. is in the Czech language classified by the grade 4, he comes from a socially disadvantaged family, he is insecure and unassertive when dealing with classmates and adults, his mental problems require outpatient treatment at children psychiatry ward. Some of his answers in the entry questionnaire were surprisingly clear and definite. Reading books is not a useful activity for him, he does not like poems but admits that their reading can be important to someone. He believes that poetry 
has no meaning nowadays and clearly declares his opposition to it. He states that the poems often seem incomprehensible and feels insecure when working with poetry, he does not expect that reading poetry could bring satisfaction to anyone and cannot imagine himself writing a poem. Not surprisingly, he added to V. Holan's text just a few words which are completely beyond the meaning of the poem and the syntactic structure of the verses (For it knows well that without did there is no firmness. I guess, God, because I feel ... From every man falls the last luck...). Like some other pupils he connects the last verse of the existence of God with the gift of life, however, he was unable to detect the point of it.

- Tereza B. is timid, suffering from inferiority complex, in a permanent opposition to her classmates and unable openly assert her opinion. In the subject of the Czech language she is classified by the grade 4 . She believes that the poems are written for a small selected group of readers, she admits her distaste for poetry and the fact she does not understand it. When working with poetry she is insecure and not interested in the discussion of literary texts. These facts are clearly reflected in the outcome of the given task. The numerous corrections in her text show that she tried to find the most appropriate expressions but final versions testify to the fact that she was not able even to guess the basic meaning of the text, some of the additions are illogical and other superficial (The last leaf sits on the plane-tree, For it knows well that without being cheap there is no firmness... From every tree falls the colourful leaf....). Her utter helplessness is suggested by the words completing the last verse (This is the end!). After the completion of the task she wrote into her diary: It's weird, nothing fits. I was completely lost.

- Sára N. is classified by the grade 3 in the Czech language, at school she is quiet and timid. In the entry questionnaire she indicated that reading books was useful in life, but did not like to read herself (nor did her parents) and expressed unambiguous dislike of poetry. However, she acknowledged that poetry had some importance nowadays (selecting 3 on the five-point scale) and believed that in a few years she could understand some poems differently. Poems were often incomprehensible for her and the literary education did not inspire her to reading poetry. She univocally believed that reading of a poem could not bring her pleasure and categorically asserted that poetry was not important for her life. She completely refused the idea that he could have fun writing poems and did not want to present her views in the literary education. Although she had not filled in some missing words, the meaning of some verses was successfully completed (I tremble, God, because I think...From every tree falls the last leaf...).

- Martin P. is a pupil diagnosed with Asperger syndrome. He is classified with the grade 3 in the Czech language, but he is very knowledgeable about natural sciences. Because of the diagnosis his social behaviour is non-appropriate for his age group, he has an issue with concentration. He is grateful for the attention of adults, 
seeks out a chance to talk with them and he is very sensitive to the slightest praise. In view of the above characteristics of the pupil, it is not surprising that when interpreting the text he favours logical connections and the first verse of Holan's poems are completed by the words The wise leaf trembles on the plane-tree, For it knows well that in old age there is no firmness... He was one of the few pupils who tried to complete the conclusion (You gave it life and it has appreciated Your hand). In the diary he had summed up his impressions of this activity: It's quite interesting, it needs a lot of thinking about, but it is not the best exercise we've done so far. I have missed all of it, it is very difficult.

The most successful and meaningful text was provided by Aneta V., she is a pupil with a significantly positive relationship to poetry. In the Czech language she is classified by the grade 2 , but in lessons she is very quiet, introverted, shy and with a low selfconfidence.

The colorful leaf trembles on the plane-tree

For it knows well that without youth there is no firmness.

I tremble, God, because I feel

I pray, I shall soon die and should be firm.

From every tree falls the strongest leaf

For it is not without faith in the earth.

From every man falls the last worry

For to believe is utterly simple.

The leaf has no need to ask you, God, for anything -

You gave it life and it has managed in Your hand.

But I...

When compared with Holan's poems, significant differences will stand out in the overall tone and meaning of the text, but there is no doubt that the pupil, although applying the text to her own images and life experiences, feels intuitively its depth and she is also capable to express her feelings appropriately (and in some cases without clichés). She described her feelings about this activity in the following words: Some words were easier and some harder. The words had been easier before. I missed it completely. Noteworthy is her statement: There was a completely different atmosphere there.

\subsection{Writing one's own poem}

The idea of writing their own poetry had initially caused uncertainty among the pupils (When the teacher told us that we would write poems, I immediately thought about a topic. I have not figured it out yet. I do not mind it is mandatory, but I cannot do it.). After 
the implementation of this activity, the attitudes changed: I liked inventing the verses. (Jakub D.). Also Markéta Ch. stated in the entry questionnaire that she could not imagine she would create a poem. When given the task she wrote in her diary: I had a very strange feeling, it seemed to me that it would not make any sense ... She, however, summed up her impressions after meeting the task: I feel good about it, on the whole l enjoyed it, I would not mind repeating it. Some pupils even handed over more then one suggested poem and in school they had together assessed the texts anonymously. The teacher's reflection shows that there had been a noticeable shift at this stage of the experiment in the relation of the children to poetry, the teacher considers it is remarkable that the most points were awarded to the poem written by a girl classified with the grade 4 in the Czech language. Dominik V. is one of the weaker pupils in the experimental class but his text deserves a special attention:

IMISS YOU...

I miss you very much,

What more can l ask for

Than to be with you,

In your shadow stand forever.

The benefit of this activity was not only a re-evaluation of pupils' own skills and confidence building. The children had also realized that some of their classmates who had not been expected to do very well created interesting poetic texts (I liked it that the guys wrote nice poems as well. I did not expect that. So many pretty poems. I'm surprised that even the weaker pupils composed nice poems, I was very surprised. I was fascinated by some nice poems my classmates came up with, I am really surprised. Some poems are very good.). The authors of the best poems won a small prize and a diploma and two of them were published in the municipal newsletter. All the texts were illustrated in art lessons, bound and displayed in the local library reading room.

\section{Progress and results of the quantitative research lines}

The five-point scale was used for the respondents to record their agreement or disagreement with a series of statements relating to poetry, methods of teaching etc. There was a total of 33 monitored items. Three of these items $(13,23,33)$ had only a complementary function and were not included in the final evaluation. In total 30 items from the questionnaire had been processesed. On a five-point scale this means that the average value of results reaches 90 points (an average evaluation by the five-point scale multiplied by the number of the items: $3 \times 30$ ). Lower values suggest a more positive attitude of the respondents to the monitored fields, higher values on the contrary 
suggest a negative relationship. While the individual pupils' attitude in the control class to the monitored phenomena had remained without significant changes, there were significant shifts both towards the positive assessment and the negative assessment in the experimental class.

In Table 1 there are the names of 20 respondents involved in the project and arranged according to their shift in the perceptions of poetry resulting from the year-long experimental teaching. There are 10 respondents with the largest positive shift and 10 with the shift to the negative assessment.

Table 1

The order of the pupils from the experimental class according to their progress in relation to poetry and its teaching

\begin{tabular}{|l|c|c|c|}
\hline Name & Input & Output & Difference \\
\hline Jakub D. & 133 & 103 & 30 \\
\hline Tereza B. & 115 & 86 & 29 \\
\hline Sára N. & 123 & 95 & 28 \\
\hline Martin P. & 116 & 91 & 25 \\
\hline Markéta Ch. & 117 & 96 & 21 \\
\hline Denisa P. & 78 & 58 & 20 \\
\hline Ondřej K. & 135 & 116 & 19 \\
\hline Tomáś B. & 87 & 73 & 14 \\
\hline Michaela N. & 135 & 123 & 12 \\
\hline Adéla T. & 76 & 64 & 12 \\
\hline Pavlína Š. & 98 & 106 & -8 \\
\hline Eliška Z. & 57 & 66 & -9 \\
\hline Martin F. & 77 & 87 & -10 \\
\hline Martin K. & 101 & 117 & -16 \\
\hline Adam Š. & 75 & 91 & -16 \\
\hline Marika Ř. & 97 & 120 & -23 \\
\hline Veronika Ch. & 88 & 114 & -26 \\
\hline Aneta V. & 76 & 105 & -29 \\
\hline Dominik V. & 72 & 112 & -40 \\
\hline Štěpán J. & 74 & 119 & -45 \\
\hline
\end{tabular}

The results of the questionnaire survey among the respondents indicate that the greatest shift recorded by the Table 1 concerns the pupils whose initial relationship could be described as a complete rejection. It can be assumed that the activating and creative work methods influenced their fear of poetry. Often they were amongst the weaker pupils (Jakub D., Tereza B., Sára N.), who were able to experience the feeling of success 
which they otherwise did not know in school. On the other hand, significant deterioration was noted in the pupils who had boycotted the activities of the teacher or were not too keen to learn in general (Štěpán J., Dominik V., Veronika Ch.), or in the case of some quiet, introverted and insecure girls whose fear of failure was blocking their creativity (Aneta V., Marika Ř.).

Table 2

The correlation between the entry attitudes and intensity of their changes

\begin{tabular}{|l|c|c|c|c|}
\hline \multirow{2}{*}{ Variable } & \multicolumn{4}{|c|}{ Correlations - experimental class } \\
& \multicolumn{4}{|c|}{$\mathbf{N = 2 9}$} \\
\cline { 2 - 5 } & Averages & Standard deviation & INPUT & DIFFERENCE \\
\hline INPUT & 97,17241 & 22,40068 & 1,0000 & $\mathbf{0 , 5 7}$ \\
\hline DIFFERENCE & $-0,72414$ & 20,26590 & $\mathbf{0 , 5 7}$ & 1,0000 \\
\hline
\end{tabular}

Note: The marked correlations are significant at the level $p<0,05000$

In Table 2, "DIFFERENCE" describes the difference between the established attitude to poetry at the beginning of the experiment (input) and after its completion. The input values capture pupils' attitudes to poetry before the start of the experiment. There was a statistically significant positive correlation shown between the variables "DIFFERENCE" and "INPUT" in the experimental class. The results of the correlation analysis can be interpreted in such a way that the higher difference values correspond to the higher input values. The pupils who at the beginning of the experiment did not show very good attitudes to poetry showed after its completion relatively frequent and substantial positive changes. The pupils who had declared at the beginning of the experiment positive attitudes to poetry did not show further positive changes and sometimes negative (undesirable) changes emerged on the completion of the experiment. It is evident from the diaries of the pupils and the observations of their teachers that the pupils have adopted a more realistic relationship to poetry. They ceased to view poetry as inaccessible art, on the contrary it has proved to be understandable and often enjoyable activity.

\section{Conclusion}

Although many of the tasks were difficult for the pupils, especially those activities in which they could use their own imagination and creativity, they perceived them as interesting and enjoyable. The feeling of success experienced during creative activities and the positive, friendly atmosphere made some of them change their originally declared attitude of resistance to poetry and realize that reading poetry could provide them with a pleasant experience. 
The teacher described the experiment as a motivating one, the new methods allowing her to use new approaches not previously introduced in her poetry lessons: The pupils have a better attitude to the work with poetry now, they are not afraid of it and I must admit that I, myself, am less "afraid" of poems and of teaching them. This is probably due to the fact that this experiment has brought up many suggestions for a different way of working with poems, which I frequently apply in my classes now. Even the pupils themselves, especially the younger ones, ask me to suggest a topic they could compose a poem on. When their "creations" are displayed on the bulletin board in the hallway or even printed in the municipal newsletter they definitely feel a great satisfaction. The teacher also welcomed the opportunity - offered by the creative work - of insight into the pupils' feelings, moods and ideas resulting in better understanding.

A joint discussion of the texts and evaluation of pupils' poetic attempts have also contributed to the development of their social and personal skills and to a deeper understanding of the fact that mutual discussions and difference of opinion can be rewarding and some a priori judgments may not correspond to reality.

This paper was prepared as part of the project GA CR P407/11/0594 Analysis of Readers' Reception of Poetic Texts in Adolescent Readers (2011-2013).

\section{References}

Certo, J. L, Apol, L., Wibbens, E. \& Yoon, S. (2010). Teaching Poetry Writing, PreK-12: A Review of Research and Suggested Directions for Teacher Practice and Development. In Troia, G. A, Shankland, R. K. \& Heintz, A. (Eds.), Putting Writing Research into Practice: Applications for Teacher Professional Development (pp. 93-114). New York: Guilford Press.

Gejgušová, I. (2009). Interpretace uměleckého textu v literární výchově na základní škole. Ostrava: Pedagogická fakulta Ostravské univerzity v Ostravě.

Hanratty, B. (2012). Poetry and Gender: A Comparative Evaluation of Boys' and Girls' Responses to Poetry at Key Stage 4 in Northern Ireland. Research Papers in Education, 26 (4), 413-426.

Homolová, K. (2008). Pedagogicko-didaktické a psychosociální aspekty pubescentního čtenářství. Ostrava: Pedagogická fakulta Ostravské univerzity v Ostravě.

Janík, T., Lokajíčková, V. \& Janko, T. (2012). Komponenty a charakteristiky zakládající kvalitu výuky: přehled výzkumných zjištění. Orbis Scholae, 6 (3), 27-55.

Lambirth, A., Smith, S. \& Steele, S. (2012). „Poetry is happening but I don't exactly know how": Literacy Subject Leaders' Perceptions of Poetry in their Primary Schools. Literacy, 46 (2), 73-80.

Lederbuchová, L. (2010). Literatura ve škole. Plzeň: Západočeská univerzita v Plzni.

Office for standards in education (2007). Poetry in Schools: A Survey of Practice 2006/2007. London: Ofsted. Dostupné z: http://www.ofsted.gov.uk/resources/poetry-schools.

Pelikán, J. (2009). Fenomén výchovy. In J. Průcha (Ed.), Pedagogická encyklopedie (pp. 19-23). Praha: Portál.

Shulman, L. S. (1987). Knowledge and Teaching: Foundations of the new reform. Harvard Educational Review, 57 (1), 1-22. 
Slavík, J., Dytrtová, K. \& Fulková, M. (2010). Konceptová analýza tvořivých úloh jako nástroj učitelské reflexe. Pedagogika, 60 (3-4), 223-241.

Vala, J. \& Fic, I. (2012). Poezie a mladí čtenáři. Výzkum recepce konkrétních básní. Olomouc: Hanex.

Vala, J. (2011). Poezie v literární výchově. Olomouc: Univerzita Palackého v Olomouci.

Vala, J. (2013). Poezie, studenti a učitelé. Recepce, interpretace, výuka. Olomouc: Univerzita Palackého.

Wiseman, A. (2011). Powerful students, powerful words: writing and learning in a poetry workshop. Literacy, 45 (2), 70-77.

\section{Contact:}

Doc. PhDr. Vlasta Řeřichová, CSc.

Katedra českého jazyka a literatury

Pedagogická fakulta

Univerzita Palackého

Žižkovo nám. 5

77140 Olomouc, Česká republika

E-mail: vlasta.rerichova@upol.cz 